interesting suggestion that perhaps the two times are a pair of concepts which are like the pair of concepts, free will and determinism - complementary in the sense of Bohr. They are two aspects of human knowledge which are both required for our understanding of the world but which exclude each other. Park hopes that this view will lead to a unification of the two times on a higher abstract level. I am sceptical, mainly because of my qualm about the neglect of the life sciences. To understand time 2 one surely should know what life is!

In all, I think that this is a stimulating book and I gladly recommend it. Each reader will undoubtedly have several objections as I had, but there is also no doubt that the book will make him think again about the roots of time.

\title{
Inheritance: the immunological challenge
}

\author{
N.A. Mitchison
}

Somatic Selection and Adaptive Evolution: On the Inheritance of Acquired Characters. By E. J. Steele. Pp.92. (Williams and Wallace: Toronto/Croom Helm: London, 1980.) \$14.95, £8.95.

THIS rather thin little book advocates the inheritance of acquired characteristics. Its interest lies in the opportunity it offers of observing how a competent young cellular immunologist came to hold such a view, and in the papers published earlier this year by the author, jointly with $\mathrm{R}$. Gorczynski of Toronto, claiming to establish the validity of such inheritance in respect of immunological reactivity. Whether this idea need be considered seriously is a matter of opinion. R. B. Taylor (Nature 286,$837 ; 1980$ ) does so. I do not, on the grounds that such an implausible claim need not be taken seriously to start with except by extreme specialists, in the sense of those willing and able to attempt to repeat the work. Otherwise, let time be the test: if Steele and Gorczynski can make something of their story - pursuing its implications and mechanisms - then let them do so. The rest of us can afford to wait and see. Fortunately, Steele shares the view that their work will stand or fall by what he can accomplish in a follow-up. For example, can heightened as well as diminished reactivity be transmitted by males to their offspring? Can genetically tolerant (heterozygous at $\mathrm{H}-2$ ) as well as experimentally tolerant males transmit?

The idea is that retroviruses transmit genes from one cell to another by picking up messenger RNA, an old speculation of Temin's. To this is added the thought that the hypothetical flow of genes will favour those genes expressed in clonally expanded cells. As ideas there is nothing wrong with these, except that they are a little old hat now that DNA transfection has become an established technique - which can be used, as M. J. Cline has shown, to transmit methotrexate resistance genes from one mouse to another. The question is whether gene transfer between cells occurs naturally on any appreciable scale. The stability of Mendelian segregation ratios argues that it

does not, particularly when account is taken of segregation from a parent carrying a non-functional allele and from females with X-chromosome inactivation. Steele does not try to rebut or even evaluate this evidence. Instead he quotes a handful of apparent exceptions. Of course, apparent exceptions will turn up if one looks hard enough, but as exceptions they surely deserve critical examination. This they do not receive here.

For instance, Steele cites the apparent transmission of "individual-specific" antibody idiotype from immunized rabbits to their offspring. But interpreting these data is tricky, because the assignment of idiotypes to the "individual-specific" as distinct from the "germline-encoded" category is doubtful. Furthermore, when a female is immunized before giving birth, as was the case for the data showing apparent transmission, there is a possibility that passively transmitted antibody may have favoured production of the idiotype in the offspring. Or to take another instance, Steele cites the apparent production of sickle-cell haemoglobin trait offspring from normal parents as evidence of gene transfer. What is critical here is whether the parents were correctly typed, and to the extent that the typing is more rigorous (that is detects smaller amounts of HbS-type haemoglobin) the argument for gene transfer is weakened. These are technical points, but they indicate the incomplete nature of Steele's argument.

Much the same applies to the musings on the history and future of Lamarckian ideas. A scholarly discussion of these topics would require a coverage of nineteenthcentury intellectual history and twentiethcentury population genetics which is not the aim here. It is particularly disappointing to find no mention of the problem of conserving genetic variation under any scheme such as that proposed.

If Steele's work can be repeated, and if his interpretation stands, here is one colleague who will most humbly eat his words.

N.A. Mitchison is Professor of Zoology at University College London.

\section{$\mathrm{B}, \mathrm{Cu}, \mathrm{Co}, \mathrm{Fe}, \mathrm{Mn}$, Mo, Zn ...}

\section{T.S. West}

Applied Soil Trace Elements. Edited by Brian E. Davies. Pp.482. (Wiley: 1980.) $£ 22.50, \$ 67.50$.

PROBLEMS associated with contamination of the environment by traces of heavy metals are of considerable concern to many scientists and laymen. Somewhat strangely, relatively little interest is shown in the equally important problems associated with deficiencies of the trace elements that are essential to all forms of life. Elements such as boron, copper, cobalt, iron, manganese, molybdenum and zinc act as essential catalytic components in most enzyme systems in plants and, boron excepted, in animals where many other elements are vital to the considerably more complex biochemical processes involved.

All trace elements in biological systems are derived from the Earth's crustal rocks originally, but come mainly via weathering of the primary minerals of the parent rocks in soils through plants and, to a lesser extent, through the water supply. This somewhat curiously titled book is a synthesis of most of our knowledge of the trace elements that are known, at the present time, to be "biosignificant". Written by agronomists, chemists and geologists, it is an excellent account which can be recommended to all who are directly concerned with these matters, to others who work in associated areas in the medical sciences and indeed to all who are scientifically aware. It is well written and in many places quite fascinating.

I would have preferred to have seen a fuller account of the chemistry, particularly chemical speciation, of these elements in the soil, and a more systematic consideration of the demands made by plants on the soil. This could have been done at the expense of the rather overdetailed account given of analytical procedures, although one of course does recognize that virtually all present traceelement work in soils is heavily dependent on advances in the analytical sciences.

However, there is no doubt that this book is a major contribution to the subject and in my opinion it is one of the most important to have been published. It is well written and illustrated, and handsomely produced. One hopes that the editor will keep the team together to produce a second edition, when many of the exciting developments that are now taking place particularly in speciation and synergism between elements - could be given as well as an account of the "new" elements.

This book deserves to be widely read and it probably will.

T.S. West is Director of the Macaulay Institute for Soil Research, Craigiebuckler, Aberdeen. 